\title{
New Cost-Effective Technologies Applied to the Study of the Glacier Melting Influence on Physical and Biological Processes in Kongsfjorden Area (Svalbard)
}

\author{
Lorenzo Pasculli ${ }^{1}$, Viviana Piermattei ${ }^{1,2}, * \mathbb{C}$, Alice Madonia ${ }^{1,2}$, Gabriele Bruzzone ${ }^{3}(\mathbb{D}$, \\ Massimo Caccia ${ }^{3}$, Roberta Ferretti ${ }^{3}\left(\mathbb{D}\right.$, Angelo Odetti ${ }^{3}(-)$ and Marco Marcelli ${ }^{1,2}$ \\ 1 Laboratory of Experimental Oceanology and Marine Ecology, Department of Ecological and Biological \\ Sciences, University of Tuscia, Molo Vespucci, Porto di Civitavecchia, 00053 Civitavecchia (RM), Italy; \\ 1.pasculli@unitus.it (L.P.); alice_madonia@unitus.it (A.M.); marcomarcell@unitus.it (M.M.) \\ 2 Euro-Mediterranean Center on Climate Change (CMCC), Via Augusto Imperatore, 16, 73100 Lecce, Italy \\ 3 CNR-INM, National Research Council, Institute of Marine Engineering, Via de Marini 6, 16149 Genova, Italy; \\ gabriele.bruzzone@cnr.it (G.B.); massimo.caccia@cnr.it (M.C.); roberta.ferretti@inm.cnr.it (R.F.); \\ angelo.odetti@inm.cnr.it (A.O.) \\ * Correspondence: v.piermattei@unitus.it
}

Received: 25 June 2020; Accepted: 5 August 2020; Published: 8 August 2020

\begin{abstract}
The Arctic region is greatly affected by climate change, with evident alterations in both physical and biological processes: temperatures are changing at a rate that is twice the global average and phytoplankton productivity is directly affected by ice melting. Continuous monitoring of this ecosystem is fundamental to gain greater understanding of the impact of changes on the natural environment, but the Global Ocean Observing System only provides partial coverage in these extreme areas, which are particularly difficult to reach. Technological progress in oceanographic measurement capabilities is indispensable for the implementation of marine observatories, especially in these remote regions. In recent years, autonomous systems and cost-effective technologies have proved to be valuable for increasing spatial and temporal coverage of data. This is the case with the innovative ArLoC (Arctic Low-Cost) probe, which was designed and developed for easy integration into various types of platforms, enabling continuous measurement of temperature, pressure and fluorescence of chlorophyll $a$. This work reports on the results of two scientific campaigns carried out in Kongsfjorden (Svalbard Islands) in 2018 in the framework of the UVASS (Unmanned Vehicles for Autonomous Sensing and Sampling) research project. The ArLoC probe was integrated onboard the PROTEUS (Portable RObotic TEchnology for Unmanned Surveys) unmanned semi-submersible vehicle and this allowed us to collect important data in the stretches of sea near tidewater glacier fronts. The acquired data showed several significant effects of glacier melting such as: high temperature and salinity gradients, which cause considerable variations in water mass stratification, and an increase in turbidity and the chlorophyll $a$ concentration, which directly affects primary productivity and the trophic chain. During the surveys, ArLoC proved to be an easy-to-integrate, very reliable instrument, which permitted high spatial resolution investigation of ecological processes during glacier melting as never studied before.
\end{abstract}

Keywords: Arctic Ocean; low-cost technology; tidewater glaciers; temperatures; chlorophyll $a$ fluorescence

\section{Introduction}

The Arctic Ocean is undergoing a rapid warming process. In the past few decades, Arctic average temperatures have increased at twice the rate observed in the rest of the world [1]. The increase in 
global temperatures is correlated to rising temperatures in the polar oceans, which directly influence ice sheets, tidewater glaciers, snowfall over high latitudes and perhaps even large-scale atmospheric circulation [2]. As a matter of fact, between the end of the 1970s and the early part of the 2000s, the extent of sea ice coverage declined as the mass of glaciers in the Arctic decreased between $3.5 \%$ and $4.1 \%$ per decade, with a marked decrease recorded in the boreal summer months with rates between $9.4 \%$ and $13.6 \%$ [3]. The reduced sea ice coverage is increasing the surface area exposed to solar radiation as well as the absorption of sunlight during the warm season: this causes a subsequent release of heat as larger portions of the Arctic Ocean become ice-free, thereby amplifying Arctic warming in the cold season [4]. Increased melting of the cryosphere increases fresh water intake into the marine environment, thus influencing physical processes, supply of nutrients and ecosystems [5].

In this contest, tidewater glaciers play a key role in the Arctic environment, as they constitute a particular connection area between land and sea. Due to global warming, the mass of tidewater glaciers is currently fluctuating [6]: the mass balance of Svalbard glaciers is currently negative, and climate change forecasts suggest continuous warming that will increase ice retreat, snow melting and glacial flows of rivers [7]. Considering the importance of tidewater glaciers, over time many oceanographic campaigns have been carried out in Arctic fjords to study the effects of their melting; however, measurements have always been carried out in the central areas, particularly for chlorophyll $a$, mainly due to poor accessibility to other areas, such as glacier fronts. Recent studies carried out at glacier fronts were made possible by deployment of autonomous underwater vehicles (AUVs), as in Howe et al. [8] and in Mankoff et al. [9]. Glacier fronts are extremely important research areas: they influence the geophysical characteristics of fjords, especially through the subglacial inputs of meltwater and sediments; they feature high concentrations of both mineral and organic nutrients, affecting the whole plankton community and they are a feeding and breeding area for many other marine organisms such as birds and marine mammals [10].

Improving our knowledge of these ecosystems would also benefit the Global Ocean Observing System (GOOS), which only offers partial data coverage in the Arctic due to the considerable cost of oceanographic instruments and extreme weather and sea conditions. Studying complex phenomena such as global climate change, biogeochemical processes and many other aspects of Arctic oceanography is no mean task, especially because of the technical challenges posed by extreme conditions in these particular environments [11]. Both the permanent ice sheet and the brief summer season drastically reduce researchers' ability to analyze an extreme environment such as the Arctic. Svalbard provides an excellent study ground, given the presence of the polar research base Ny-Ålesund [12] and, in this scenario, autonomous underwater vehicles (AUVs) represent a precious tool for recording Arctic data. AUVs are mostly used to make measurements under the ice, in order to study, for example, heat fluxes and the distribution of benthic populations, which provide key information for understanding the rapid change in the Arctic climate and ecosystems [13]. Over time, these platforms have become increasingly effective thanks to the implementation of different types of instruments and sensors for the study of physical, chemical and bio-optical variables [13]. The success of autonomous platforms has therefore encouraged the development of sensors that exploit and integrate currently available low-cost methods for ocean study [13]. To reduce the cost of instruments and oceanographic platforms, the scientific community has developed cost-effective technologies for marine research, in an attempt to considerably reduce the cost of oceanographic surveys and ultimately improve data coverage and repeatability of any kind of campaign [14-16]. Using cost-effective technologies may help us to provide in situ data for remote sensing validation and validation of mathematical models, which are essential to cover wide temporal and spatial scales and forecast processes that are not yet fully understood.

In this context, an autonomous system was tested with cost-effective technology for the acquisition of physical and bio-optical data in areas adjacent to the glacier fronts.

This work reports on a preliminary study of physical and bio-optical properties observed near glacier fronts in the Kongsfjorden region, through the application of a new cost-effective technology (ArLoC) on board an autonomous platform (PROTEUS). The experiment was conducted within the 
UVASS (Unmanned Vehicles for Autonomous Sensing and Sampling) research project, whose goal is to develop automated oceanographic platforms to perform water and ice sampling in dangerous areas, such as tidewater glacier fronts [17].

\section{Materials and Methods}

\subsection{Study Area}

Kongsfjorden is a sub-polar fjord located on the west coast of Spitsbergen, the largest island in the Svalbard archipelago, at $79^{\circ} 57^{\prime} \mathrm{N}$ and $12^{\circ} 04^{\prime} \mathrm{E}$ [12]. Kongsfjorden is oriented from southeast to northwest and is $20 \mathrm{~km}$ long. Its width varies from 4 to $10 \mathrm{~km}$, reached at the mouth between Kvadehunken and Kapp Guissez [18]. The fjord's bathymetry varies from less than $100 \mathrm{~m}$, reached in the innermost area, to $300 \mathrm{~m}$ in the most external area [18]. There are five large perennial coastal glaciers: Kronebreen, Kongsvengen and Kongsbreen, in the inner part, and Blomstrandbreen and Conwaybreen on the north coast (Figure 1).

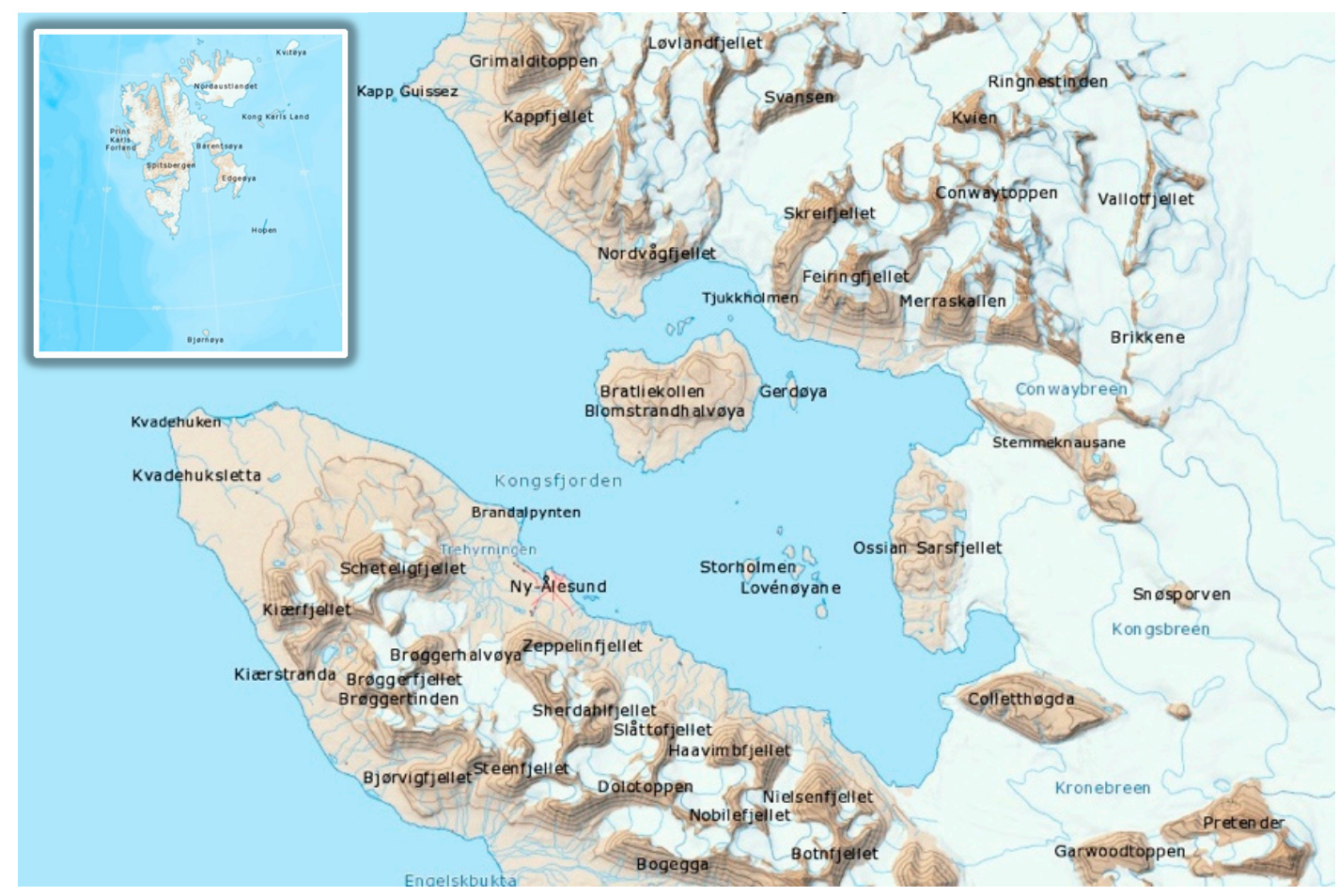

Figure 1. Map of Svalbard (Norway) and Kongsfjorden (Norsk Polar Institute).

Together with the currents entering the fjord, these glaciers have a strong influence on the physical, chemical, and biological characteristics of the Kongsfjorden. The west coast of Svalbard is profoundly affected by the passage of the North Atlantic current, which carries relatively warm $\left(>3^{\circ} \mathrm{C}\right)$ and salty (>34.9 PSU) waters in the West Spitsbergen Current (WSC) [18]. From the heart of the WSC derives the Atlantic Water (AW), which joins the Arctic Water (ArW) and enters the Kongsfjorden system thanks to the particular topography of the continental shelf: the absence of a step allows easier access by the external waters in the fjord [18].

The innermost part of the fjord, on the other hand, is characterized by the presence of fresh surface water (SW), resulting from the dissolution of the cryospheric component [18]. Much of the freshwater flow derives from the melting of coastal glaciers, which inject water through three main processes: direct subglacial melting of the glacier terminus, convection-driven melt and frontal ablation [19]. These processes, mainly convection-driven melt and frontal ablation, are usually strongly influenced by the presence of the AW entering the fjord in the summer. Due to climate change and global 
warming, a concomitant increase in the temperature of the AW and a weakening of the ArW have been created, leading to more significant AW warm incursions, which slow down the formation of sea ice at the interior of the fjord, and the melting of coastal glaciers increases for more extended periods [8] Furthermore, the increase in outflow volumes produced by deep-discharged glaciers can trigger further submarine melting of the ice surface [20], forming a positive feedback mechanism that increases submarine melting.

This flow of freshwater plays a key role in the circulation of glacial fjords: especially during the summer, the presence of these masses of water creates a particular two-layer circulation, in which the low-density SW will exit the fjord. In response, there will be a seasonal influx of AW from the WSC and intermediate salinity coastal waters, typically following the southern coast into the fjord [18]. However, this circulation will not only be characterized by the exchange of masses of water of different densities, but in the internal and more superficial part of the fjord, the local circulation driven by the wind will become relatively more important. In fact, as well as in the summer, this guarantees substantial circulation in the inner fjord even in the winter season, when there is no outflow from the glaciers [21].

Seasonal variations also cause the formation of further water masses already classified in Svendsen et al. [18] and Cottier et al. [20] and reported in Table 1.

Table 1. Definitions for water masses found in Kongsfjorden and on the adjacent shelf [18].

\begin{tabular}{ccccc}
\hline Water Mass & Abbreviation & \multicolumn{3}{c}{ Characteristics } \\
\cline { 3 - 5 } & & T $\left({ }^{\circ} \mathbf{C}\right)$ & Sal (PSU) & $\left.\mathbf{\sigma} \mathbf{( k g} / \mathbf{m}^{\mathbf{3}}\right)$ \\
\hline Atlantic water & AW & $>3$ & $>34.65$ & $<27.92$ \\
Transformed Atlantic water & TAW & 1 to 3 & $>34.65$ & $<27.92$ \\
Arctic water & ArW & -1.5 to 1 & 34.3 to 34.8 & \\
Surface water & SW & $>1$ & $<34$ & \\
Intermediate water & IW & $>1$ & 34 to 34.65 \\
Local water & LW & -0.5 to 1 & 34.3 to 34.85 & \\
Winter cooled water & WCW & $<-0.5$ & 34.4 to 35.0 & \\
\hline
\end{tabular}

The different physical factors that influence the fjord are fundamental for the structuring of biodiversity in the Kongsfjorden: in particular, the strong gradients of the water, the presence of ice, fresh water inputs and the particulate deriving from glacier melting induce great changes in the bloom and composition of phytoplankton communities throughout the year, from the inner to the outer parts of the fjord. Light is the main limiting factor that regulates phytoplankton production: during the long polar night, there is a complete absence of autotrophic organisms [12]. Phytoplankton blooms occur in spring, when ice melting begins, and light penetrates $(>30 \mathrm{~m})$ deeper into the water column [22]. Turbidity increases from spring to summer, due to the transport of particulates by the glaciers, thus affecting the productivity of the phytoplankton biomass. In autumn, the phytoplankton biomass decreases completely, and disappears with the beginning of the winter season, only maintaining a few forms of resistance [12].

This area is also important because it attracts fish and large predators such as seals, sea birds and polar bears, thanks to the phytoplankton blooms that derive their nourishment from the nutrients released into the sea by the melting glaciers $[10,12]$.

\subsection{Survey Strategy}

The survey was conducted on 1 June 2018, along two transects performed in two different areas: the first one in front of Kongsbreen glacier $\left(78^{\circ} 57.645^{\prime} \mathrm{N}, 12^{\circ} 36.940^{\prime} \mathrm{E}\right)$, and the second one in front of Conwaybreen glacier $\left(78^{\circ} 59.172^{\prime} \mathrm{N}, 12^{\circ} 32.829^{\prime}\right.$ E) (Figure 2).

The transects started at the glacier front and covered a $600 \mathrm{~m}$ line perpendicular to the glacier front to collect data both at the surface and in the water column. Each transept lasted an hour and a half. The profiles reached a maximum depth of $27 \mathrm{~m}$ in front of the Kongsbreen glacier, analyzing only 
the surface part of the water column. In fact, according to the bathymetry studied by Howe et al. [8], it shows a maximum depth of $160 \mathrm{~m}$ and a minimum of $25 \mathrm{~m}$. Instead, in front of the Conwaybreen glacier, the maximum depth is $54 \mathrm{~m}$, and the profiles investigated almost the entire water column, reaching $36 \mathrm{~m}$ [8]. The surveys were carried out using the PROTEUS (Portable RObotic TEchnology for Unmanned Surveys) vehicle, a marine robot purposely designed for the Arctic environment by the Marine Robotics research group at the Institute of Marine Engineering of the National Research Council (Genoa, Italy). PROTEUS can function as an ROV, an AUV or a USSV [17]. The vehicle is easily customizable since it can be reconfigured upon each mission according to specific needs by installing and shifting different payloads. In these campaigns, PROTEUS was used as a USSV (unmanned semi-submersible vehicle) (Figure 3) [17].

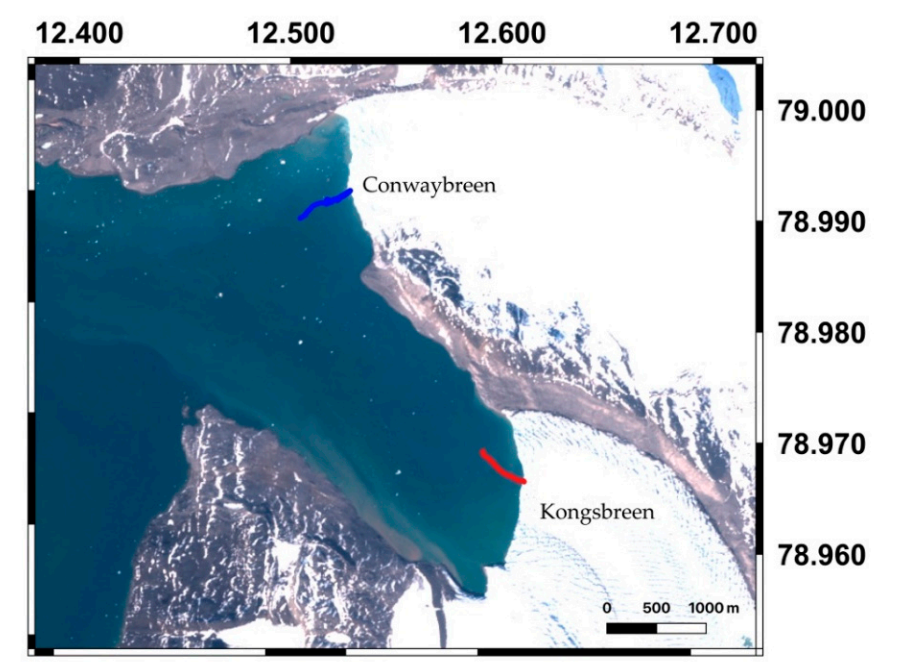

Figure 2. Map of Portable RObotic TEchnology for Unmanned Surveys (PROTEUS) tracks; Sentinel 2-B image obtained on 7 June 2018.

The vehicle was remotely controlled by a $9 \mathrm{~m}$ boat (MS Teisten). The PROTEUS communication system, which allows the pilot to communicate with the robot, is made up of two different radio systems in order to guarantee redundancy for safety reasons. The first Wi-Fi radio system operates at $2.4 \mathrm{GHz}$ and allows us to send commands for driving the vehicle, and to receive telemetry and a video stream from the camera on the vehicle. The second radiomodem system, which operates at $437 \mathrm{MHz}$, allows the user to send/receive basic and limited telemetry commands and data (no video is available for this channel due to bandwidth limitations). This second channel is used for saving the vehicle in case of problems with the Wi-Fi connection. In addition, in the event that both radio communications are completely lost, a control mechanism located in the robot control system stops all the actuators so that PROTEUS can be safely pulled closer to the support boat by means of a rope Dyneema and recovered [23]. Data of different variables were collected through the deployment of various probes. Temperature and fluorescence of chlorophyll $a$ were acquired by ArLoC (Arctic Low-Cost probe), a cost-effective probe developed by the Laboratory of Experimental Oceanology and Marine Ecology (Civitavecchia, Italy). ArLoC is based on a previous low cost, modular expandable probe [24], which was upgraded to permit easy integration onto different oceanographic platforms. In Piermattei et al. [16], ArLoC's efficiency was demonstrated in comparison to commercial probes. In addition to the ArLoC probe, two commercial probes were installed on PROTEUS: an Idronaut 305 Plus CTD to acquire salinity and depth values, and a Turbidimeter Cyclops-7 Turner Design to analyze values of turbidity near glacier fronts. All the probes (ArLoC, CTD and turbidimeter) were released into the sea by means of an electrical winch in order to study the whole water column from the sea-bottom up to the surface. 


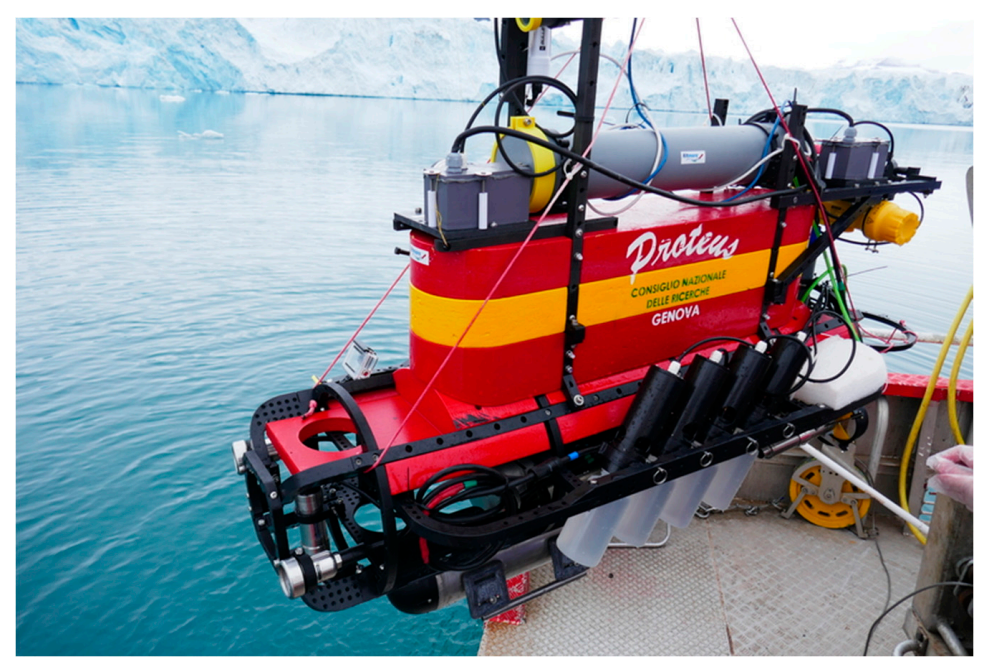

Figure 3. PROTEUS vehicle.

The winch was mounted on the stern of PROTEUS and was remotely controlled by the operators (Figure 4). The recorded position is that of the GPS on the surface vehicle. The underwater position of the CTD is estimated at a point which, for shallow depths (and little current), can be considered within the uncertainty of the GPS measurement but which obviously degrades with increasing depth and current.

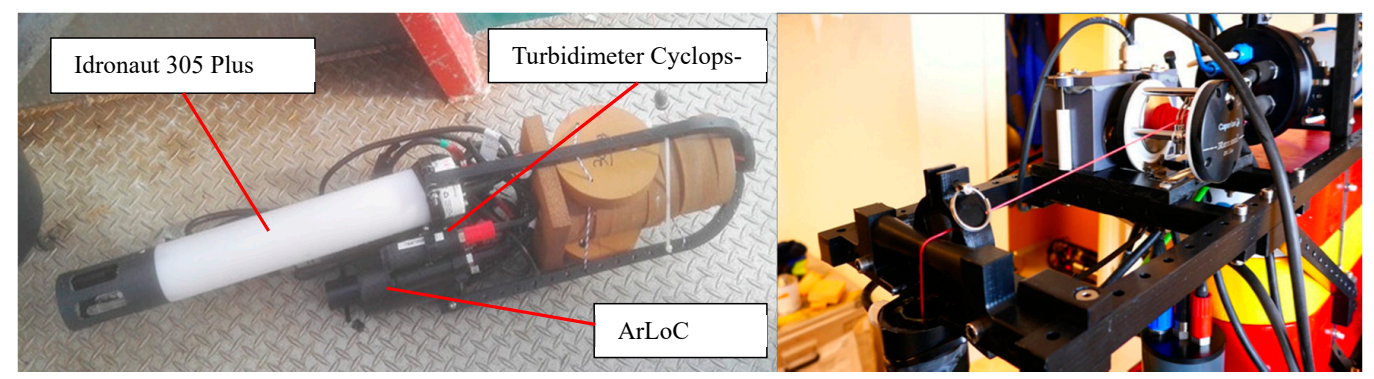

Figure 4. Probes installed on PROTEUS and winch system.

All the data from the probes were collected, synchronized and saved using the MPDACS (Multi-Purpose Data Acquisition Control System), a custom data logger developed by the Marine Robotics research group at CNR-INM. The collected data were analyzed and graphically represented through the interpolation of the profiles in the water column with Ocean Data View software.

All ArLoC sensors were calibrated in the laboratory following standard procedures before and after the campaign [25], while commercial probes were factory adjusted before the beginning of the survey.

\section{Results}

\subsection{Kongsbreen}

During the survey, low temperatures were recorded in front of the Kongsbreen glacier (ranging from -0.21 to $1.69^{\circ} \mathrm{C}$ ). Increasing temperatures were recorded across the stations: the lowest temperatures were recorded in the $\mathrm{K} 2$ and $\mathrm{K} 3$ profiles, nearest to the glacier front, with values ranging, respectively, from -0.21 to $1.09^{\circ} \mathrm{C}$ in $\mathrm{K} 2$ and from -0.17 to $1.42{ }^{\circ} \mathrm{C}$ in $\mathrm{K} 3$; in $\mathrm{K} 6$ and $\mathrm{K} 7$, respectively, at about 400 and $500 \mathrm{~m}$ from the glacier, temperatures ranged from 0.09 to $1.69^{\circ} \mathrm{C}$ and from -0.11 to $1.68^{\circ} \mathrm{C}$. Along the water column, temperatures showed a constant decrease in all profiles, with higher values near the surface. In K2, at about $200 \mathrm{~m}$ from the glacier, a plume of cooler water rising from the depths was recorded (Figure 5a). 

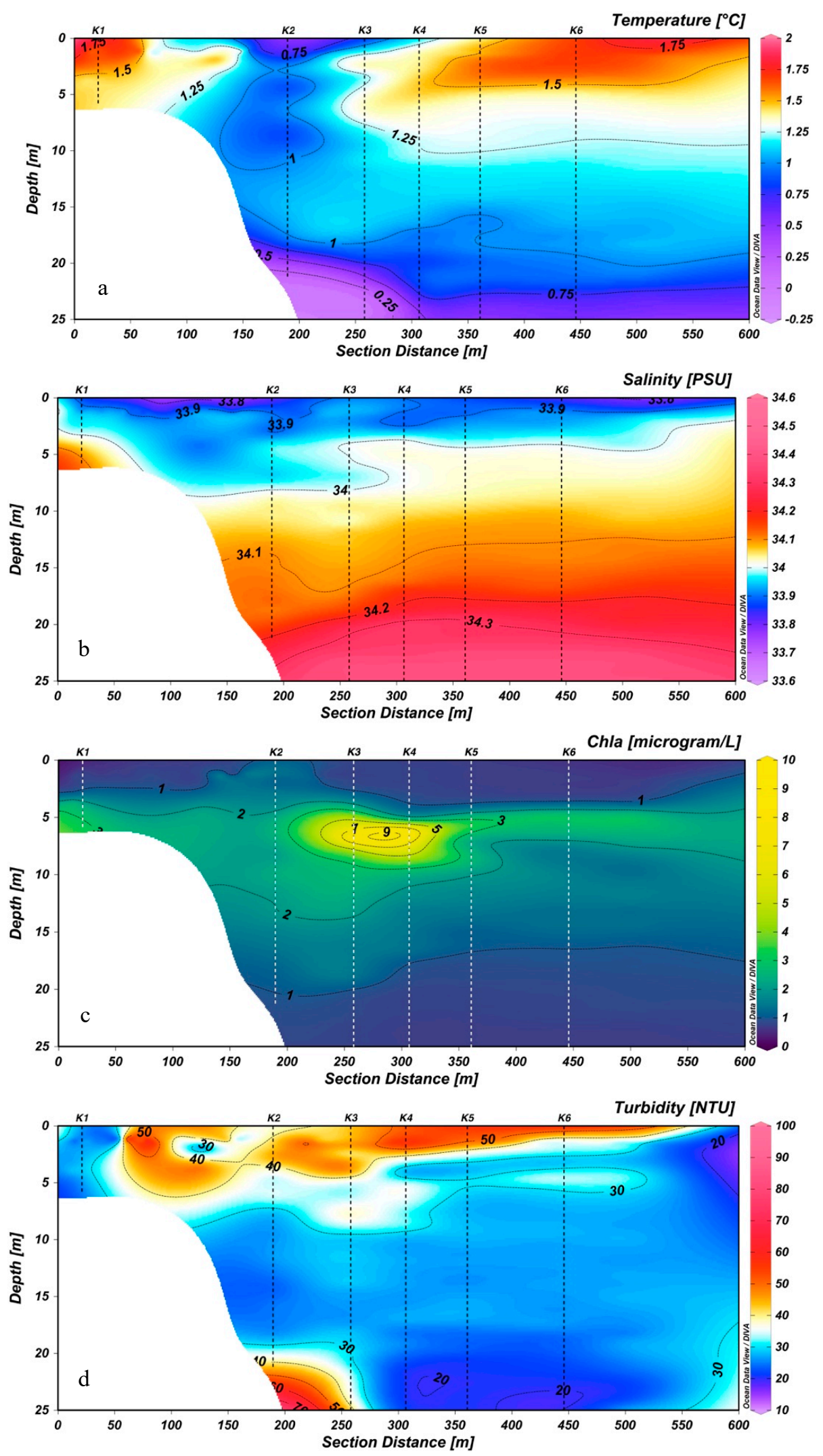

Figure 5. Representation of the distribution of the variables acquired in the Kongsbreen area along the water column: (a) temperature, (b) salinity, (c) chlorophyll $a$, (d) turbidity; dashed lines show the position of vertical profiles. 
Salinity is constant in the waters bordering the glacier, but differs vertically in the water column: fresher water was found near the surface (ranging between 33.85 and 33.92 PSU) and saltier water was measured in the depths (34.51-35.54 PSU) (Figure 5b).

Concerning analysis of the phytoplankton bloom, ArLoC data show that the highest chlorophyll $a$ peak (concentration of $10.18 \mu \mathrm{g} / \mathrm{L}$ ) was found at a depth of about $6 \mathrm{~m}$ at a distance from the glacier front ranging between $200 \mathrm{~m}$ and $300 \mathrm{~m}$. Other small patches of phytoplankton were recorded at a depth of about $5 \mathrm{~m}$ from the glacier front. In the upper layer, chlorophyll $a$ showed the lowest values $(<2 \mu \mathrm{g} / \mathrm{L}$ ) between $20 \mathrm{~m}$ and $25 \mathrm{~m}$ (Figure $5 \mathrm{c}$ ).

Turbidity values vary between 10 and 100 NTU, reaching the highest levels in correspondence with the upper layers. Lower values were recorded below $10 \mathrm{~m}$ in all stations. A higher concentration of suspended matter was only found in $\mathrm{K} 1$ at depths between $20 \mathrm{~m}$ and $25 \mathrm{~m}$ (Figure 5d).

\subsection{Conwaybreen}

Temperatures in the waters bordering Conwaybreen glacier ranged from -0.44 to $1.64{ }^{\circ} \mathrm{C}$. Temperatures varied along the water column, with higher values near the surface and lower values at the bottom. Moving away from the glacier front, temperatures showed an increase in the range measured in all profiles, ranging from 0.88 to $1.50{ }^{\circ} \mathrm{C}$ in $\mathrm{C} 1$ and from -0.44 to $1.64{ }^{\circ} \mathrm{C}$ in $\mathrm{C} 7$, respectively, at a distance of about 70 and $570 \mathrm{~m}$ from the glacier front (Figure 6a).

Salinity is lower on the surface (with values below 33.8 PSU), and gradually increases deeper down the water column (S ranging from 33.78 to 34.53 PSU) (Figure $6 \mathrm{~b}$ ).

The highest peak in chlorophyll $a$ was recorded at a distance between about 400 and $600 \mathrm{~m}$ from the glacier (the highest value was $36.59 \mu \mathrm{g} / \mathrm{L}$ ). At a depth of about $5 \mathrm{~m}$, a deep chlorophyll maximum (DCM) was recorded in all profiles, showing a well-structured phytoplankton patch (concentration ranging from 4.37 to $36.59 \mu \mathrm{g} / \mathrm{L}$ in DCM) (Figure 6c).

The turbidimeter registered high concentrations of suspended matter near the surface, reaching 100.6 NTU at about $500 \mathrm{~m}$ from the glacier. Concentrations of suspended matter were recorded in all profiles along the water column, in particular in C3, where the values were never below 30 NTU (Figure 6d).

\subsection{Water Masses}

A temperature-salinity (T-S) diagram representing the water masses surrounding the two glacier fronts is shown in Figure 7. According to the definitions given by Svendsen et al. [18] and Cottier et al. [26], three water masses were identified in the fjord basin: SW, IW and LW, with characteristics summarized in Table 1. The stratification of water masses is due to freshwater runoff from glaciers, which creates SW characterized by salinity values below 34 PSU and temperatures above $1.0^{\circ} \mathrm{C}$. IW is created by the merging of SW and LW (occurring during winter), and was the deepest water mass found in the profiles. In Figure 7, Kongsbreen data show values which do not correspond to any water mass: they are characterized by salinity values between 33.5 and 34 PSU and temperatures below $1.0^{\circ} \mathrm{C}$. Water in front of Kongsbreen glacier has density anomalies $(\sigma)$ ranging from 27.0 to 27.8 $\mathrm{kg} / \mathrm{m}^{3}$, unlike water bordering Conwaybreen glacier, where values range between 26.6 and $27.8 \mathrm{~kg} / \mathrm{m}^{3}$. 

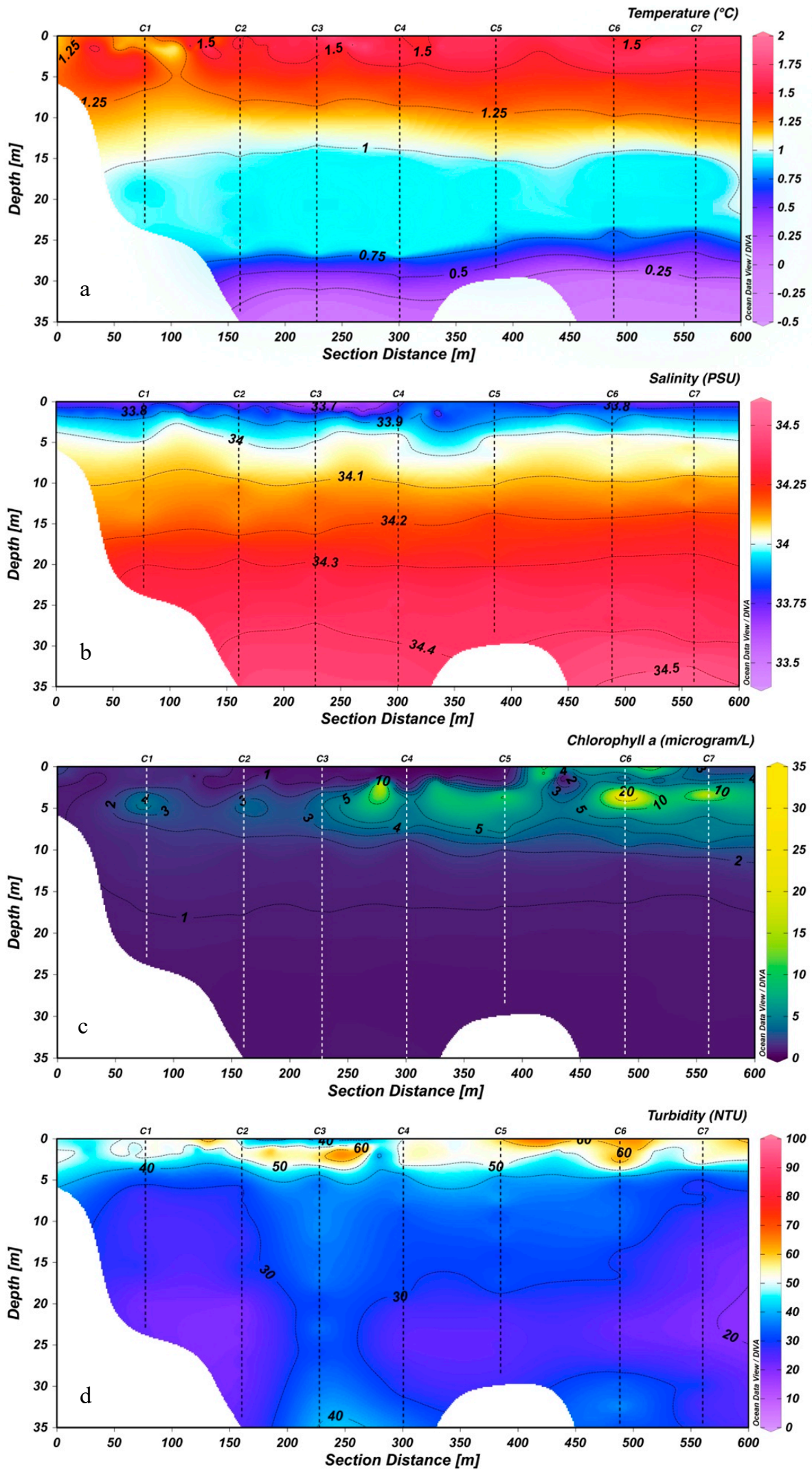

Figure 6. Representation of the distribution of the variables acquired in the Conwaybreen area along the water column: (a) temperature, (b) salinity, (c) chlorophyll $a$, (d) turbidity; dashed lines show the position of vertical profiles. 


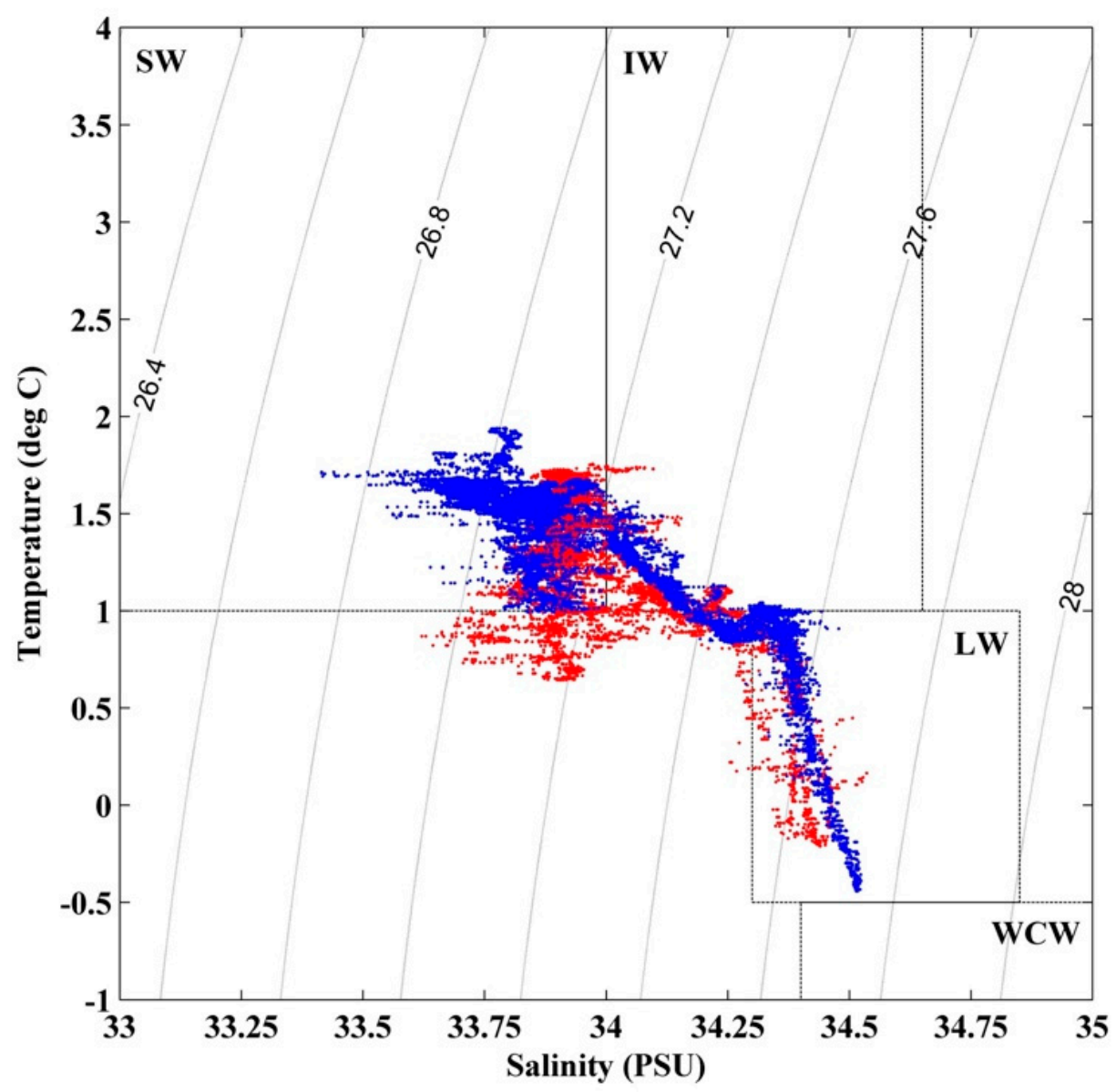

Figure 7. Temperature-salinity diagram: red dots show water in front of Kongsbreen glacier; blue dots show water in front of Conwaybreen glacier.

\section{Discussions}

In our study, we were able to carry out first-hand observations that would otherwise have been impossible with traditional methods and thus obtained preliminary information on how physical and bio-optical variables are modified in the areas in direct contact with the glaciers.

The output of glacier meltwater reaches the marine environment in three main ways: superficial melting of the glacier, which, however, represents only a small share of the contribution; direct contact of relatively warmer fjord waters with the glacier front and high flow leakage of fresh water from underwater channels. Characterized by low temperatures, as descripted in Mankoff et al. [9] and Luckman et al. [27], this meltwater reaches the surface thanks to its low density, the discharge flux and the water column's weak stratification [28]. Once the melt plume reaches the surface, it spreads towards the fjord, further entraining the subsurface water at a speed dependent on relative density and flow velocity [10]. Analysis of water column data acquired in the vicinity of Kongsbreen glacier allowed us to observe one of these subglacial plumes of cold water, which rises from the bottom to the surface (Figure 8). Characterized by a temperature ranging between 0.7 and $1.0^{\circ} \mathrm{C}$ and salinity ranging from 33.8 to $34.0 \mathrm{PSU}$, this water is also visible in the T-S diagram (Figure 7), with a density anomaly ranging between 26.6 and $27.8 \mathrm{~kg} / \mathrm{m}^{3}$ : these characteristics are in line with those shown in other works on subglacial melting $[9,19,29-32]$. 


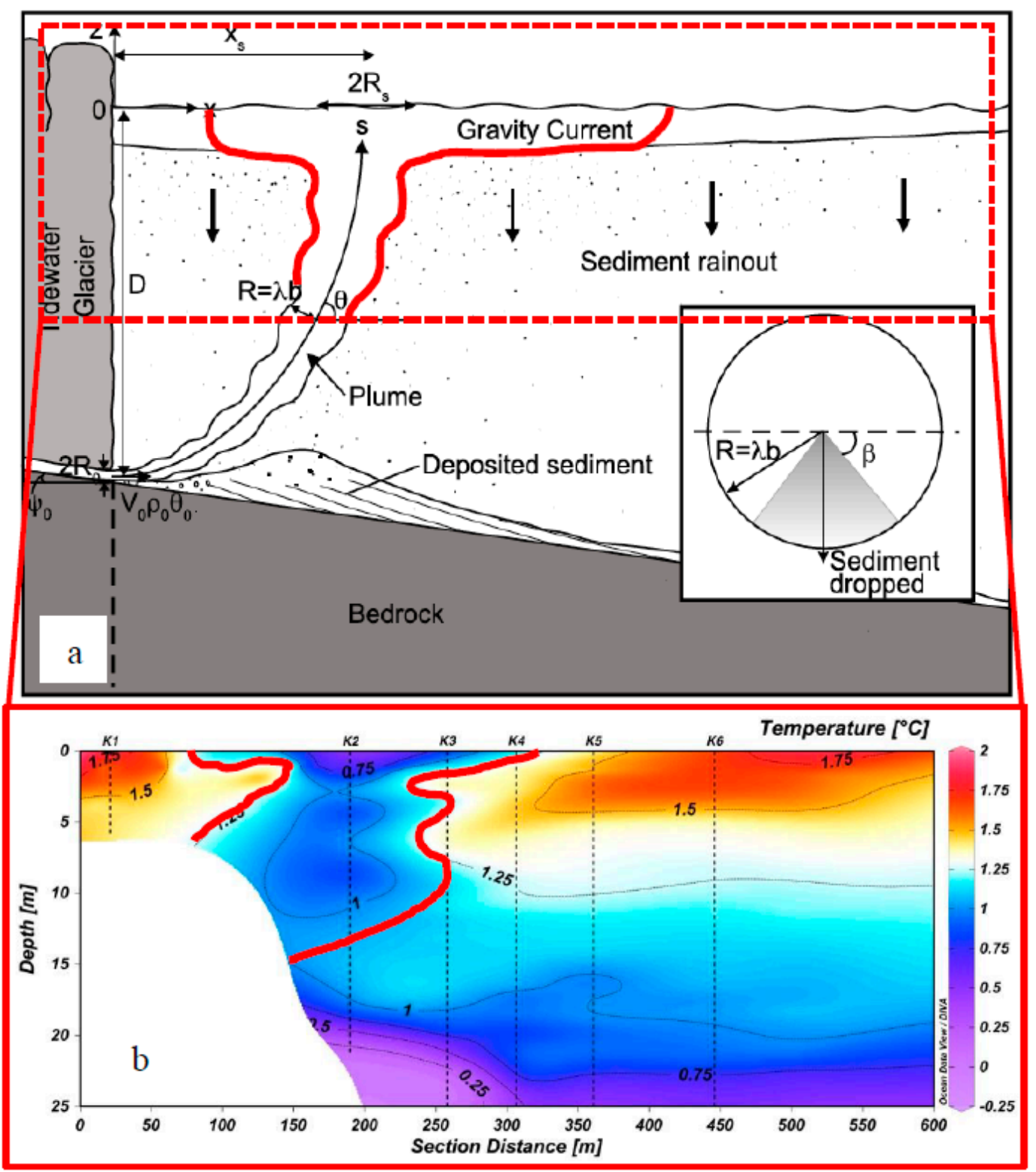

Figure 8. Comparison between the Mugford and Dowdeswell [29] model (a) and the temperature section in front of the Kongsbreen glacier. (b) Red boundaries show the correlation between the assumed plume and the rise of cold water observed in the section in front of the Kongsbreen glacier.

As further confirmation, the rise of subglacial meltwater was reported in Schild et al. [19] in the same area where our sampling was carried out.

On the other hand, the sections obtained in front of the Conwaybreen glacier do not show the presence of a plume. This, as studied by Howe et al. [8], could be due to the progressive recession of the Conwaybreen glacier. In fact, as noted in Howe et al. [8], part of the Conwaybreen glacier is now land-terminating. This would therefore lead to the inflow of freshwater only at the surface level without the formation of an active plume. Moreover, as modelled in other works, this could be due also to different factors: during the early ice melting season, the discharge flux is not strong enough to reach the surface [30]; an elevated presence of sediment might affect the density of the plume, preventing it from reaching the surface and stratifying at an intermediate depth; a meltwater plume stratifies at intermediate depth because of high stratification [10] and moreover, the transept samples only a tiny part of the glacier front so the subglacial plume may have originated elsewhere. 
Rising through the water column, meltwater could transport sediment to the surface, as demonstrated in Mugford and Dowdeswell [25] and Meslard et al. [28]. Turbidity data acquired during our surveys (Figure 5d) show an important upwelling of suspended matter at about $200 \mathrm{~m}$ from the glacier front, corresponding to a cold-water rising zone in the temperature section (Figure 5a). Moreover, in Figure 5d, Kongsbreen turbidity values show a high concentration of suspended matter below the plume, at a depth of about $25 \mathrm{~m}$, but also in the rest of the water column values persist at about 30 NTU. This process could be due to the precipitation of the sediments brought to the surface by the plume. In fact, in other works, the sedimentation of suspended matter has been studied: moving away from the glacier, the material brought to the surface by the plumes begins to sediment again due to a greater density, thus being detected by the instruments also along the water column $[29,33]$.

Through the rise of organic and inorganic material, an important supply of nutrients is obtained in marine waters, showing that ice and snow melting leads to a strong increase in nutrients in polar waters [34]. These nutrients, in particular $\mathrm{N}$ and $\mathrm{Si}$, are correlated with a phytoplankton biomass increase [34]. Improved access to glacier fronts made it possible to observe that the chlorophyll $a$ concentration was considerably higher in areas near glaciers, with peaks of $35 \mu \mathrm{g} / \mathrm{L}$ in front of Conwaybreen glacier. These values are higher than those reported in previous works: the values in these areas have always been between 12.5 and $15.5 \mu \mathrm{g} / \mathrm{L}[7,35,36]$. However, these samplings were carried out at a distance of several kilometers from glaciers, the closest one kilometer from the glacier [7]. In this work, the timing of the chlorophyll $a$ concentration peak seems to be correlated to rising temperature values in winter months: in van De Poll et al. [7], a mid- and late-May bloom was reported as a consequence of high temperatures recorded in winter months due to an intrusion of AW into the fjord system. In early January 2018, the AWIPEV Underwater Observatory reported temperatures of $2.1{ }^{\circ} \mathrm{C}$ at $11 \mathrm{~m}$, in line with findings reported in van de Poll et al. [36] in 2014. Other mid-late May blooms were reported in 2003, 2004, 2007, 2010 and 2012 [7,35,37,38], and were characterized by an intrusion of AW in winter months. AW intrusion into Kongsfjorden affects phytoplankton blooms: increased subglacial melt, due to high temperatures of AW, enhances the supply of suspended matter and nutrients into the marine environment [28] and intensifies stratification of water masses, stabilizing the phytoplankton near the surface [36].

High turbidity values, however, might have a negative impact on phytoplankton growth. In the area facing Kongsbreen glacier, chlorophyll $a$ was not concentrated mainly within the observed plume, but rather on its sides: this is probably due to strong turbidity, which limits light penetration, the main limiting factor for phytoplankton growth in these areas [7,36,39]. In fact, during the late summer, when glacier melting and the addition of sediments in the water column are greater, the euphotic zone near the glaciers can be found at depths as low as $0.3 \mathrm{~m}$ [7].

As demonstrated by Piermattei et al. [16], ArLoC has shown high data acquisition effectiveness. As further confirmation, a comparison of the temperature data obtained in this work in front of the Kongsbreen glacier was performed. In addition, during the 2018 campaign, data obtained by the ArLoC correctly overlap those obtained by the Idronaut probe (Figure 9a). Linear regression has been applied, which shows a correlation with $R^{2}=0.95$ (Figure $9 b$ ). The demonstrated effectiveness of this low-cost probe is further proof of how the development of cost-effective instrumentation is a fundamental point for the future of oceanography study. The current cost of oceanographic instrumentation remains high, but numerous projects are being applied to develop equipment that guarantees useful data collection at lower costs.

Although many advances have been made in technological innovation for the study of the seas and oceans, today, there is still a growing need for technological improvement regarding the development of sensors and measuring platforms. For this reason, the success in the development and operation of platforms such as PROTEUS is significant, able to perform detailed studies in areas with extreme conditions and difficult to reach, as demonstrated in Bruzzone et al. [23]. The modularity of PROTEUS makes it suitable for the study of different and dangerous areas in complete autonomy, thus making it reusable and reducing campaign times and therefore costs. 


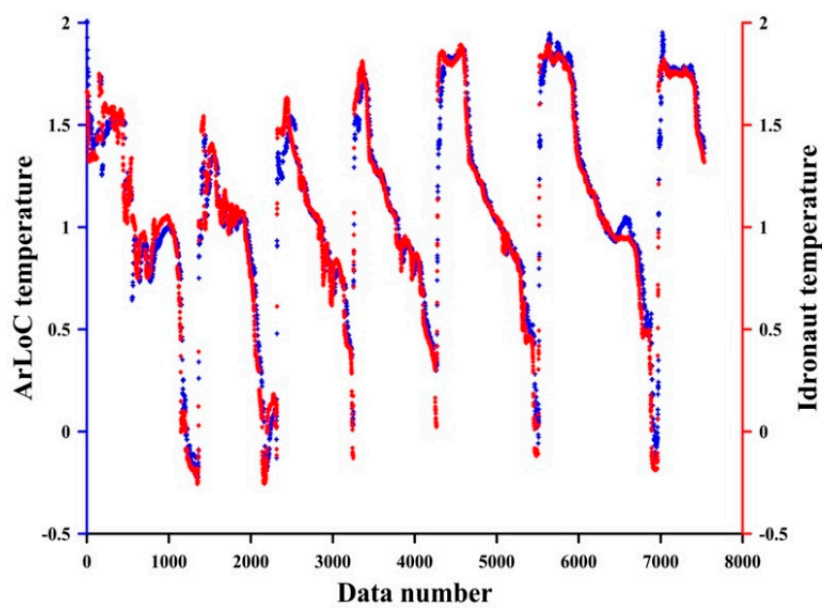

(a)

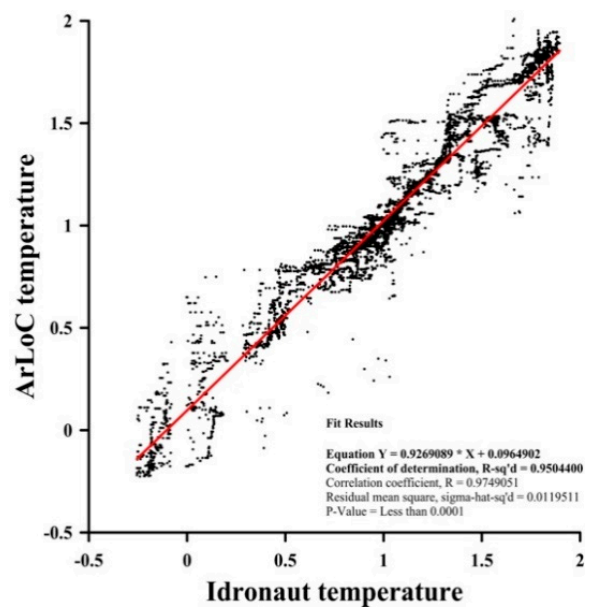

(b)

Figure 9. (a) Temperature trend acquired during the transect along Kongsbreen glacier, blue for Arctic Low-Cost probe (ArLoC) data and red for the Idronaut 305 Plus data; (b) comparison between ArLoC and Idronaut temperature sensors.

\section{Conclusions}

In this preliminary work, we observed how tidewater glacier melting affects the marine environment of Kongsfjorden, inducing a massive phytoplankton bloom with a concentration peak of $35 \mu \mathrm{g} / \mathrm{L}$, probably due to the supply of nutrients from subglacial discharge. However, continuous warming processes and climate change are affecting the Arctic region, greatly influencing the ecosystems. Glaciers are increasingly retreating, thus changing the physical and bio-optical characteristics of these environments, such as increased turbidity, earlier stratification of water masses and lower salinity. For this reason, it is necessary to improve future prospects in the monitoring of extreme environments and perform widespread measurements to study below-surface variables indicating climate change, such as the behavior and distribution of phytoplankton linked to ice melting.

Although much progress has been made in technological innovation for the study of Arctic seas, there is still a growing need for technological development, both in terms of platform development and more cost-effective sensors. These developments must take into account the spatial and temporal scales of oceanographic phenomena, but also the cost-effectiveness of data acquisition systems. This will allow efficient comparison with satellite data and assimilation to mathematical models, which require large amounts of data for their validation. This aspect is crucial for biological measurements, as they have very small scales variation. For this reason, the development of autonomous platforms, such as the PROTEUS, equipped with cost-effective technologies, such as the ArLoC, is particularly significant as it allows data collection in areas and periods that are otherwise inaccessible due to extreme conditions. This will enable researchers to study these environments in a totally innovative way and collect data that, until a few years ago, were completely unknown or just barely conceivable.

Author Contributions: L.P., V.P., A.M., G.B., M.C., R.F., A.O., M.M., L.P. and V.P. conceived and designed the experiments; L.P., V.P., A.M., G.B. and A.O. performed the experiments; L.P., V.P., A.M. and R.F. performed data analysis and drafted the manuscript; and M.C., G.B. and M.M. supervised the project. All the authors reviewed and approved the final manuscript.

Funding: The survey carried out in 2018 in the Kongsfjorden was funded by the European Union under the Horizon 2020 Programme, Twinning Project EXCELLABUST (Excelling LABUST in marine robotics), grant agreement N. 691980. 
Acknowledgments: The authors wish to thank Giorgio Bruzzone, Mauro Giacopelli and Edoardo Spirandelli for their fundamental fieldwork, design and development contribution before and during the polar scientific campaign. The authors also wish to thank all the staff of the CNR Polar Research Coordination Unit "Polarnet" and of the Dirigibile Italia station in Ny-Ålesund for their kind and professional support.

Conflicts of Interest: The authors declare no conflict of interest.

\section{References}

1. Arctic Climate Impact Assessment (ACIA). Impacts of a Warming Arctic: Arctic Climate Impact Assessment. Cambridge University Press: Cambridge, UK, 2004; ISBN 0521617782.

2. Walsh, J.E.; Overland, J.E.; Groisman, P.Y.; Rudolf, B. Ongoing Climate Change in the Arctic. Ambio 2011, 40, 6-16. [CrossRef]

3. Intergovernmental Panel on Climate Change (IPCC). Climate Change 2013-The Physical Science Basis. Intergovernmental Panel on Climate Change, Ed.; Cambridge University Press: Cambridge, UK, 2014; ISBN 9781107415324.

4. Dai, A.; Luo, D.; Song, M.; Liu, J. Arctic amplification is caused by sea-ice loss under increasing CO2. Nat. Commun. 2019, 10, 121. [CrossRef] [PubMed]

5. Torsvik, T.; Albretsen, J.; Sundfjord, A.; Kohler, J.; Sandvik, A.D.; Skarðhamar, J.; Lindbäck, K.; Everett, A. Impact of tidewater glacier retreat on the fjord system: Modeling present and future circulation in Kongsfjorden, Svalbard. Estuar. Coast. Shelf Sci. 2019, 220, 152-165. [CrossRef]

6. Husum, K.; Howe, J.A.; Baltzer, A.; Forwick, M.; Jensen, M.; Jernas, P.; Korsun, S.; Miettinen, A.; Mohan, R.; Morigi, C.; et al. The marine sedimentary environments of Kongsfjorden, Svalbard: An archive of polar environmental change. Polar Res. 2019, 38, 1-16. [CrossRef]

7. Calleja, M.L.; Kerhervé, P.; Bourgeois, S.; Kędra, M.; Leynaert, A.; Devred, E.; Babin, M.; Morata, N. Effects of increase glacier discharge on phytoplankton bloom dynamics and pelagic geochemistry in a high Arctic fjord. Prog. Oceanogr. 2017, 159, 195-210. [CrossRef]

8. Howe, J.A.; Husum, K.; Inall, M.E.; Coogan, J.; Luckman, A.; Arosio, R.; Abernethy, C.; Verchili, D. Autonomous underwater vehicle (AUV) observations of recent tidewater glacier retreat, western Svalbard. Mar. Geol. 2019, 417, 106009. [CrossRef]

9. Mankoff, K.D.; Straneo, F.; Cenedese, C.; Das, S.B.; Richards, C.G.; Singh, H. Structure and dynamics of a subglacial discharge plume in a Greenlandic fjord. J. Geophys. Res. Ocean. 2016, 121, 8670-8688. [CrossRef]

10. Lydersen, C.; Assmy, P.; Falk-Petersen, S.; Kohler, J.; Kovacs, K.M.; Reigstad, M.; Steen, H.; Strøm, H.; Sundfjord, A.; Varpe, $\varnothing$.; et al. The importance of tidewater glaciers for marine mammals and seabirds in Svalbard, Norway. J. Mar. Syst. 2014, 129, 452-471. [CrossRef]

11. Vihma, T.; Uotila, P.; Sandven, S.; Pozdnyakov, D.; Makshtas, A.; Pelyasov, A.; Pirazzini, R.; Danielsen, F.; Chalov, S.; Lappalainen, H.K.; et al. Towards an advanced observation system for the marine Arctic in the framework of the Pan-Eurasian Experiment (PEEX). Atmos. Chem. Phys. 2019, 19, 1941-1970. [CrossRef]

12. Hop, H.; Pearson, T.; Hegseth, E.N.; Kovacs, K.M.; Wiencke, C.; Kwasniewski, S.; Eiane, K.; Mehlum, F.; Gulliksen, B.; Wlodarska-Kowalczuk, M.; et al. The marine ecosystem of Kongsfjorden, Svalbard. Polar Res. 2002, 21, 167-208. [CrossRef]

13. Bellingham, J.G.; Rajan, K. Robotics in Remote and Hostile Environments. Science 2007, 318, $1098-1102$. [CrossRef] [PubMed]

14. Trevathan, J.; Johnstone, R.; Chiffings, T.; Atkinson, I.; Bergmann, N.; Read, W.; Theiss, S.; Myers, T.; Stevens, T. SEMAT-The Next Generation of Inexpensive Marine Environmental Monitoring and Measurement Systems. Sensors 2012, 12, 9711-9748. [CrossRef] [PubMed]

15. Lockridge, G.; Dzwonkowski, B.; Nelson, R.; Powers, S. Development of a Low-Cost Arduino-Based Sonde for Coastal Applications. Sensors 2016, 16, 528. [CrossRef] [PubMed]

16. Piermattei, V.; Madonia, A.; Bonamano, S.; Martellucci, R.; Bruzzone, G.; Ferretti, R.; Odetti, A.; Azzaro, M.; Zappalà, G.; Marcelli, M. Cost-Effective Technologies to Study the Arctic Ocean Environment †. Sensors 2018, 18, 2257. [CrossRef] [PubMed]

17. Bruzzone, G.; Odetti, A.; Caccia, M. Remote Data Collection Near Marine Glacier Fronts Unmanned Vehicles for Autonomous Sensing, Sampling in the North Pole. Sea Technol. 2018, 59, 22-26. 
18. Svendsen, H.; Beszczynska-Møller, A.; Hagen, J.O.; Lefauconnier, B.; Tverberg, V.; Gerland, S.; Børre Ørbæk, J.; Bischof, K.; Papucci, C.; Zajaczkowski, M.; et al. The physical environment of Kongsfjorden-Krossfjorden, an Arctic fjord system in Svalbard. Polar Res. 2002, 21, 133-166. [CrossRef]

19. Schild, K.M.; Renshaw, C.E.; Benn, D.I.; Luckman, A.; Hawley, R.L.; How, P.; Trusel, L.; Cottier, F.R.; Pramanik, A.; Hulton, N.R.J. Glacier Calving Rates Due to Subglacial Discharge, Fjord Circulation, and Free Convection. J. Geophys. Res. Earth Surf. 2018, 123, 2189-2204. [CrossRef]

20. Kimura, S.; Holland, P.R.; Jenkins, A.; Piggott, M. The Effect of Meltwater Plumes on the Melting of a Vertical Glacier Face. J. Phys. Oceanogr. 2014, 44, 3099-3117. [CrossRef]

21. Sundfjord, A.; Albretsen, J.; Kasajima, Y.; Skogseth, R.; Kohler, J.; Nuth, C.; Skarðhamar, J.; Cottier, F.; Nilsen, F.; Asplin, L.; et al. Effects of glacier runoff and wind on surface layer dynamics and Atlantic Water exchange in Kongsfjorden, Svalbard; a model study. Estuar. Coast. Shelf Sci. 2017, 187, 260-272. [CrossRef]

22. Sloughter, T.M.; Banas, N.S.; Sambrotto, R.N. Seasonal variation in light response of polar phytoplankton. J. Mar. Syst. 2019, 191, 64-75. [CrossRef]

23. Bruzzone, G.; Odetti, A.; Caccia, M.; Ferretti, R. Monitoring of Sea-Ice-Atmosphere Interface in the Proximity of Arctic Tidewater Glaciers: The Contribution of Marine Robotics. Remote Sens. 2020, 12, 1707. [CrossRef]

24. Marcelli, M.; Piermattei, V.; Madonia, A.; Mainardi, U. Design and Application of New Low-Cost Instruments for Marine Environmental Research. Sensors 2014, 14, 23348-23364. [CrossRef] [PubMed]

25. Jeffrey, S.W.; Wright, S.W.; Mantoura, R.F.C. Phytoplankton pigments in oceanography: Guidelines to modern methods. Unesco Publishing: Paris, France, 2005.

26. Cottier, F.; Tverberg, V.; Inall, M.; Svendsen, H.; Nilsen, F.; Griffiths, C. Water mass modification in an Arctic fjord through cross-shelf exchange: The seasonal hydrography of Kongsfjorden, Svalbard. J. Geophys. Res. 2005, 110, C12005. [CrossRef]

27. Luckman, A.; Benn, D.I.; Cottier, F.; Bevan, S.; Nilsen, F.; Inall, M. Calving rates at tidewater glaciers vary strongly with ocean temperature. Nat. Commun. 2015, 6, 8566. [CrossRef] [PubMed]

28. Chauché, N.; Hubbard, A.; Gascard, J.-C.; Box, J.E.; Bates, R.; Koppes, M.; Sole, A.; Christoffersen, P.; Patton, H. Ice-ocean interaction and calving front morphology at two west Greenland tidewater outlet glaciers. Cryosphere 2014, 8, 1457-1468. [CrossRef]

29. Mugford, R.I.; Dowdeswell, J.A. Modeling glacial meltwater plume dynamics and sedimentation in high-latitude fjords. J. Geophys. Res. Earth Surf. 2011, 116. [CrossRef]

30. Xu, Y.; Rignot, E.; Menemenlis, D.; Koppes, M. Numerical experiments on subaqueous melting of Greenland tidewater glaciers in response to ocean warming and enhanced subglacial discharge. Ann. Glaciol. 2012, 53, 229-234. [CrossRef]

31. Xu, Y.; Rignot, E.; Fenty, I.; Menemenlis, D.; Flexas, M.M. Subaqueous melting of Store Glacier, west Greenland from three-dimensional, high-resolution numerical modeling and ocean observations. Geophys. Res. Lett. 2013, 40, 4648-4653. [CrossRef]

32. Meslard, F.; Bourrin, F.; Many, G.; Kerhervé, P. Suspended particle dynamics and fluxes in an Arctic fjord (Kongsfjorden, Svalbard). Estuar. Coast. Shelf Sci. 2018, 204, 212-224. [CrossRef]

33. Zajaczkowski, M. Sediment supply and fluxes in glacial and outwash fjords, Kongsfjorden and Adventfjorden, Svalbard. Polish Polar Res. 2008, 29, 59-72.

34. Hawkings, J.R.; Wadham, J.L.; Tranter, M.; Lawson, E.; Sole, A.; Cowton, T.; Tedstone, A.J.; Bartholomew, I.; Nienow, P.; Chandler, D.; et al. The effect of warming climate on nutrient and solute export from the Greenland Ice Sheet. Geochem. Perspect. Lett. 2015, 94-104. [CrossRef]

35. Hegseth, E.N.; Tverberg, V. Effect of Atlantic water inflow on timing of the phytoplankton spring bloom in a high Arctic fjord (Kongsfjorden, Svalbard). J. Mar. Syst. 2013, 113-114, 94-105. [CrossRef]

36. van De Poll, W.H.; Maat, D.S.; Fischer, P.; Rozema, P.D.; Daly, O.B.; Koppelle, S.; Visser, R.J.W.; Buma, A.G.J. Atlantic Advection Driven Changes in Glacial Meltwater: Effects on Phytoplankton Chlorophyll-a and Taxonomic Composition in Kongsfjorden, Spitsbergen. Front. Mar. Sci. 2016, 3, 1-11. [CrossRef]

37. Leu, E.; Falk-Petersen, S.; Kwaśniewski, S.; Wulff, A.; Edvardsen, K.; Hessen, D.O. Fatty acid dynamics during the spring bloom in a High Arctic fjord: Importance of abiotic factors versus community changes. Can. J. Fish. Aquat. Sci. 2006, 63, 2760-2779. [CrossRef] 
38. Kubiszyn, A.M.; Piwosz, K.; Wiktor, J.M.; Wiktor, J.M. The effect of inter-annual Atlantic water inflow variability on the planktonic protist community structure in the West Spitsbergen waters during the summer. J. Plankton Res. 2014, 36, 1190-1203. [CrossRef]

39. Piquet, A.M.-T.; van de Poll, W.H.; Visser, R.J.W.; Wiencke, C.; Bolhuis, H.; Buma, A.G.J. Springtime phytoplankton dynamics in Arctic Krossfjorden and Kongsfjorden (Spitsbergen) as a function of glacier proximity. Biogeosciences 2014, 11, 2263-2279. [CrossRef]

(c) (i)

(C) 2020 by the authors. Licensee MDPI, Basel, Switzerland. This article is an open access article distributed under the terms and conditions of the Creative Commons Attribution (CC BY) license (http://creativecommons.org/licenses/by/4.0/). 